\title{
Rural development in the Sertão do São Francisco, Bahia: an interpretation based on the trajectories of peasant families of the territory
}

\author{
Desenvolvimento rural no Sertão do São Francisco, Bahia: uma interpretação a \\ partir de trajetórias de famílias agricultoras do território

\section{Desarrollo rural en el Sertão do São Francisco, Bahia: una interpretación de las trayectorias de familias campesinas del territorio}

\author{
Denis Monteiro ${ }^{1}$ \\ Cezar Augusto Miranda Guedes ${ }^{1}$
}

Received on: 13/12/2019; reviewed and approved on 26/02/2020; accepted on 21/03/2020 DOI: http://dx.doi.org/10.20435/inter.v22i1.2856

\begin{abstract}
This article addresses the trajectories of peasant families of the rural areas in the municipalities of Juazeiro, Casa Nova, Campo Alegre de Lourdes, and Remanso, in the Sertão do São Francisco territory, semiarid Bahia, Brazil. It aims to interpret the processes of rural development in the territory based on the results of innovations incorporated by families from the interaction in learning networks mobilized by nongovernmental organizations and access to a set of public policies. The Lume method was used to guide the economic and ecological analysis of agroecosystems. In its recent history, this territory was the beneficiary of several policies of tackling misery and hunger through Zero Hunger (Fome Zero) and Brazil without Extreme Poverty (Brasil sem Miséria) governmental programs, aimed at peasant farming. The incidence of extensive territorial development policies conducted by innovative institutionalities is another feature that called the attention of the research. A significant ensemble of innovations has been incorporated to the agroecosystems, to which contributed the public policies of the democratic period and, most importantly, the social capital of the territory resulted from the mobilization of the peasantry as well as from their partner organizations. The trajectories of analyzed families show how food production for self-consumption of the families, the reciprocity of give-and-take actions and the trading in a big diversity of local markets, while empowering the families' struggle for autonomy, also contributes to summon social active strength for the construction of rural development alternatives aimed at both making peasant farming stronger and ensuring food sovereignty of the territory.
\end{abstract}

Keywords: peasant farming; traditional communities of fundo de pasto; food security; innovations; regional development.

Resumo: O artigo aborda as trajetórias de famílias agricultoras de áreas rurais dos municípios de Juazeiro, Casa Nova, Campo Alegre de Lourdes e Remanso, no território Sertão do São Francisco, semiárido da Bahia. Tem como objetivo interpretar os processos de desenvolvimento rural no território com base em resultados de inovações incorporadas pelas famílias a partir da interação em redes de aprendizagem mobilizadas por organizações não governamentais e do acesso a um conjunto de políticas públicas. Foi utilizado o método Lume de análise econômico-ecológica de agroecossistemas. Na história recente, este território foi beneficiário de diversas políticas de enfrentamento da pobreza e da fome nos marcos dos programas Fome Zero e Brasil sem Miséria, com ações direcionadas à agricultura familiar. A incidência de políticas abrangentes de desenvolvimento territorial operacionalizadas por institucionalidades inovadoras é outra característica que chama atenção. Um conjunto expressivo de inovações foi incorporado aos agroecossistemas, para o qual contribuíram as políticas públicas do período democrático e, fundamentalmente, o capital social do território, fruto das mobilizações do campesinato e das organizações que os assessoram. As trajetórias das famílias analisadas mostram como a produção de alimentos para o autoconsumo das famílias, para alimentar as relações de reciprocidade com as doações e trocas e para a comercialização em uma grande diversidade de mercados do território, ao mesmo tempo que fortalece a luta das famílias por autonomia, contribui para reunir forças sociais ativas na construção de alternativas de desenvolvimento rural orientadas pelo fortalecimento da agricultura familiar e da soberania alimentar do território.

Palavras-chave: agricultura familiar; comunidades tradicionais de fundo de pasto; segurança alimentar; inovações; desenvolvimento regional.

\footnotetext{
${ }^{1}$ Rural Federal University of Rio de Janeiro (UFRRJ), Rio de Janeiro, Rio de Janeiro, Brazil.
} 
Resumen: El artículo aborda las trayectorias de familias campesinas de las áreas rurales de los municipios de Juazeiro, Casa Nova, Campo Alegre de Lourdes y Remanso, en el territorio del Sertão do São Francisco, semiárido de la provincia de Bahia, Brasil. Su objetivo es interpretar los procesos de desarrollo rural en el territorio a partir de los resultados de las innovaciones incorporadas por las familias a partir de la interacción en redes de aprendizaje movilizadas por organizaciones no gubernamentales y el acceso a un conjunto de políticas públicas. Se utilizó el método Lume de análisis económico y ecológico de los agroecosistemas. En la historia reciente, este territorio se ha beneficiado de diversas políticas para abordar la pobreza y el hambre en el marco de los programas Hambre Cero (Fome Zero) y Brasil sin Miseria (Brasil sem Miséria), con acciones dirigidas a la agricultura familiar. La incidencia de políticas integrales de desarrollo territorial operacionalizadas por institucionalidades innovadoras es otra característica que llama la atención. Se incorporó un conjunto significativo de innovaciones en los agroecosistemas, para lo cual contribuyeron las políticas públicas del período democrático y, fundamentalmente, el capital social del territorio, como resultado de la movilización de los campesinos y las organizaciones que los ayudan. Las trayectorias de las familias analizadas muestran cómo la producción de alimentos para el autoconsumo de las familias, para alimentar relaciones recíprocas con donaciones e intercambios y para comercializar en una gran diversidad de mercados territoriales, al tiempo que fortalece la lucha de familias por autonomía, contribuye a unir fuerzas sociales activas en la construcción de alternativas de desarrollo rural guiadas por el fortalecimiento de la agricultura familiar y la soberanía alimentaria del territorio.

Palabras claves: agricultura familiar; comunidades tradicionales de fundo de pasto; seguridad alimentaria; innovaciones; desarrollo regional.

\section{INTRODUCTION}

This article discusses the trajectories of peasant families in rural areas in the municipalities of Juazeiro, Casa Nova, Campo Alegre de Lourdes and Remanso, in the Sertão do São Francisco territory, in the semiarid region of Bahia. It aims to interpret the processes of rural development in the territory based on the results of innovations incorporated by families interacting through learning networks mobilized by non-governmental organizations and access to a set of public policies ${ }^{2}$.

The territory of the Sertão do São Francisco ${ }^{3}$ is a fertile field for debates on rural development. Contrasting development strategies are very evident, one of the main ones being the contrast between the agribusiness supply chains - fruit and tomato, onion and watermelon cultivation in irrigation projects near the São Francisco River or on the banks of the Sobradinho lake, with intensive use of agrochemicals; and the rainfed areas of fundo de pasto ${ }^{4}$ communities, where family farming predominates, dedicated to the breeding of goats and sheep and to the manioc, corn and bean fields for the territory's markets, in addition to beekeeping and chicken rearing and the cultivation of vegetables and some fruit trees around the house and the extraction of native plants from the caatinga, such as umbu, a native passion fruit and several medicinal plants.

In recent history, the territory has benefited from several policies to fight poverty and hunger within the frameworks of the Fome Zero (Zero Hunger) and Brasil Sem Miséria (Brazil Without Extreme Poverty) programs, with actions aimed at family farming. It is widely recognized that

\footnotetext{
${ }^{2}$ We would like to thank our peer reviewers for their contributions to improving this article

${ }^{3}$ Ten municipalities are part of the territory: Campo Alegre de Lourdes, Pilão Arcado, Remanso, Casa Nova, Sento Sé, Sobradinho, Juazeiro, Curaçá, Uauá and Canudos, occupying a total area of $61,000 \mathrm{~km}^{2}$. Data from IBGE in 2010 indicate a population of around 500,000 inhabitants, of which $36 \%$ live in rural areas. If we exclude the municipalities of Juazeiro and Sobradinho, which have a greater concentration of the population in urban areas, numbers indicate that $51 \%$ of the inhabitants live in rural areas.

${ }^{4}$ In the territories of the Sertão do São Francisco and Piemonte Norte do Itapicuru, 414 communities have been certified by the government of the State of Bahia as traditional fundo de pasto (community pasture) communities (www.sepromi.ba.gov. br/2019/08/2245/Sepromi-entrega-mais-54-certificacoes-de-communities-de-fundo-de-pasto.html, accessed on 09/01/2019).
} 
it was in the rural regions of the northeastern semiarid where there was a significant reduction in the number of people in situations of extreme poverty (FAVARETO et al., 2015; GRISA; SCHNEIDER, 2015). Schneider (2010) notes that one of the scholars who had great influence on rural development policies, since the beginning of the Lula government in 2003, was José Graziano da Silva, one of the creators of the Zero Hunger Program. According to the author, this intellectual policy maker saw the need to allocate social and compensatory policies to the rural poor, as well as providing rural areas with better infrastructure. In fact, this social and aid framework (GRISA; SCHNEIDER, 2015) resulted in a broad set of policies in the territory, which were fundamental for the significant reduction of poverty. But our hypothesis is that we cannot explain the long-term changes that have happened since redemocratization - rural development in this territory, without considering other policies guided by the other two references identified by the authors: agricultural and agrarian, and the construction of new markets with a focus on food security and sustainability.

The incidence of comprehensive territorial development policies operated by innovative institutions is another feature that draws attention. The Sertão do São Francisco is one of the 27 (twenty-seven) Identity Territories established by the State of Bahia since $2014^{5}$. In the territory, the Pró-Semiárido Program has also been developed since 2015, implemented through a partnership between the Development and Regional Action Company (CAR), a government agency in Bahia, and civil society organizations that directly assist rural communities territories, through participatory planning and training and activities that promote the structuring of family farms establishments and communities ${ }^{6}$.

Schneider (2010) highlights the importance of developing studies on rural development that are not guided by policy makers and mediators, since their great political influence ends up restricting research approaches, which for the author should prioritize the understanding of strategies of farming families and other social actors in the processes of social change. There is a great and relevant heterogeneity of agricultural trajectories that occur with the processes of rural development. Ploeg (2011) states that farmers observe the context to formulate new strategies, and the farming styles they practice help them to face "market failures" better, increasing resilience to turbulent contexts. Inspired by the authors, to interpret rural development, we will adopt this path towards the specific, at the level of micro analysis,

[...] the place where trends, forecasts, price relations, changes in agrarian policies or any other macro cause are actively interpreted and transformed by farmers (and other subjects) into an attitude, thus creating the macro effects that actually occur. (PLOEG, 2016, p. 29, translated from Portuguese).

\footnotetext{
${ }^{5}$ State Law n. 13,214, of December 29, 2014, established the Territorial Development Policy of the State of Bahia, instituted the State Council for Territorial Development - CEDETER and the 27 (twenty-seven) Territorial Collegiates of Sustainable Development - CODETER's. According to the official website of the state government, "in order to identify thematic priorities defined from the local reality, enabling balanced and sustainable development between regions, the Government of Bahia started to recognize the existence of 27 Identity Territories, constituted based on the specificity of each region. Its methodology was developed based on the feeling of belonging, where communities, through their representations, were invited to give their opinion (www.seplan.ba.gov.br/modules/conteudo/conteudo.php?conteudo=55, accessed on 09/01/2019).

${ }^{6}$ The program is the result of a loan agreement from the government of the State of Bahia with the International Fund for Agricultural Development (IFAD) of the United Nations (UN). Coordinated by the Rural Development Secretariat (SDR) through CAR, it is investing BRL 300 million, involving 70 thousand families in 32 municipalities in the semiarid region of Bahia, among which are all ten municipalities in the Sertão do São Francisco (http://www.car.ba.gov.br/node/182, accessed on July 3, 2019). The following organizations, members of the Semi-Arid Articulation of Bahia (ASA-BA), are responsible for implementing the program in the communities: APPJ, ARESOL, CACTUS, COOPERCUC, COFASPI, COOPSER, IDESA, IRPAA, SASOP and SAJUC.
} 
The hypothesis that guides the study is that, in the processes of rural development in the territory, an expressive set of innovations was incorporated into the agroecosystems managed by peasant families, for which public policies of the democratic period and, fundamentally, the social capital of this territory contributed, as a result of the mobilizations of the peasant movements and the organizations that advise them.

The article is organized in five sections. After this introduction, the methodological procedures are presented. In the third section, there is a brief presentation on the territorial context, emphasizing the guidelines of the State and the social capital of the territory. Section 4 is dedicated to the micro level, to the economic-ecological analysis of five agroecosystems managed by peasant families in the four municipalities. In the fifth section, we present an interpretation of the changes that occurred in the territory, analyzing rural development based on the trajectories of families.

\section{METHODOLOGICAL PROCEDURES}

The field research was carried out in 2019 with five peasant families from rural communities in four municipalities in the territory (two in Juazeiro, one in Casa Nova, one in Remanso and one in Campo Alegre de Lourdes) based on the application of the "Lume method: economicecological analysis of agroecosystems" developed by the Non-Governmental Organization (NGO) AS-PTA - Family Farming and Agroecology ${ }^{7}$ (PETERSEN et al., 2017).

The five families accessed several public policies and are currently beneficiaries of the Pró-Semiárido Program. The selection of families for the research was made by the technical teams of three NGOs that assist them within the scope of the Program - Regional Institute of Appropriate Small Agriculture (IRPAA), responsible for advising the families of Juazeiro and Remanso; Advisory Service to Popular Rural Organizations (SASOP), in Campo Alegre de Lourdes, and Social and Environmental Assistance Service in the Countryside and City (SAJUC), in the municipality of Casa Nova. The choice of families met the criterion of having at least one of its members actively participating in the program's activities.

Between April and October 2019, members of technical teams from the three NGOs, assisted by AS-PTA, conducted semi-structured interviews with families that manage agroecosystems ${ }^{8}$. The following methodological instruments recommended by the Lume method were used to survey and orderly record information: a) crossings (walks) through establishments to identify production subsystems and land capital; b) elaboration of maps of the productive units; c) elaboration of explanatory models to represent the trajectories of the constitution of agroecosystems over time (timelines) and the origins of the inputs consumed and the destination of the products generated

\footnotetext{
${ }^{7}$ Advisory and Project Services in Alternative Agriculture (AS-PTA) is a non-governmental organization based in Rio de Janeiro, which develops local development programs in partnership with family farming organizations in the countryside of Paraiba, in south-central Paraná and in the metropolitan region of Rio de Janeiro. It is dedicated to participating in spaces for the formulation and monitoring of public policies and to the development of methodological approaches aimed at family farming and guided by the principles of agroecology.

${ }^{8}$ We thank the technical advisors Bruna Ribeiro, Daiane Dantas, Dannielle Martins, Dulce Ferreira, Gildete Lima and Maiara Carvalho and Eduardo Araújo, from the teams of the organizations mentioned, for conducting the field research with the five families and for reviewing the texts. We would also like to thank the other technicians from SAJUC, SASOP and IRPAA and other non-governmental organizations active in the territory, for the coordination and technical team of the Pro-Semiárido/Regional Development and Action Company (CAR)/SDR/Government of the State of Bahia and the AS-PTA/pedagogical coordination for the training of the executive teams of the Pró-Semiárido on the Lume method: Paulo Petersen, Luciano Silveira, Paulo Neto, Cinara Sanches and Claudemar Mattos.
} 
in the agroecosystems (flow diagrams); d) spreadsheet for recording quantitative information on the economy of the agroecosystem (amount produced, rents and productive costs) over a period of one year. For each agroecosystem, some systemic attributes were analyzed, including autonomy and social integration. Following the Lume method, each sustainability attribute is analyzed based on the qualitative assessment of a set of parameters. For that, innovations registered in the agroecosystems timelines were identified. Each parameter was evaluated twice, using the configuration of the agroecosystem at two different moments in its trajectory (in 2019 and in another reference year). Assessments are carried out according to the following rating scale: 1 -very low; 2 - low; 3 - moderate; 4 - high; 5 -very high. Justifications for the ratings assigned to the parameters were recorded in a table. The attribute analyzes were carried out collectively, involving members of the technical teams of the advisory organizations, the AS-PTA and technicians from the Regional Development and Action Company (CAR/Pró-Semiárido). Radar charts were composed from the notes assigned to the parameters, generating a visual representation of the qualitative changes in the analyzed attributes. Synthetic indexes (from zero to one) were also produced to represent the relative level of each attribute at different moments in the trajectory of the agroecosystem. The quantitative data collected in the field were inserted in the Lume online platform and generated the indicators, graphs and indices on the economy of agroecosystems.

\section{CONTEXT: THE SERTÃO DO SÃO FRANCISCO TERRITORY}

\subsection{State guidance}

During the military government, the State worked intensely in the territory for the implementation of irrigated perimeters, carrying out infrastructure projects and directing agricultural credit and technical assistance policies to spread the technologies of the Green Revolution. With the re-democratization, despite the continued support of State agencies to the agrochemical model, the focus of part of the policies has changed significantly due to the growing recognition of family farming and the strengthening of social movements that called for the attention to the precarious conditions of life in the poor peasant communities and demanded specific policies. From the beginning of the 1990s, public debate on the environment and sustainability and several studies, referenced in European cases, on the multifunctionality of agriculture and rural territories, which shed light on the various functions fulfilled (economic reproduction of rural families, promotion of food security for rural families and society, maintenance of the social and cultural arrangement and reproduction of natural resources and the rural landscape), also contributed to changes in the focus of policy towards family farming: (CAZELLA; BONNAL; MALUF, 2009).

Beginning in the 1990s and more intensely in the 2000s, the notion of rural development was used as a political affirmation of family farming by civil society actors and public policy makers (SCHNEIDER, 2010). In fact, a large part of the public policies that affected the territory of the Sertão do São Francisco have family farmers as their target audience and are guided by references beyond the diffusion of the technological foundation of the Green Revolution.

In the territory, the four key elements identified by Schneider (2004) in the studies that advocated the resumption of the debate on rural development are present in the public agenda: the eradication of poverty, the issue of the role of social actors and their political participation, the territory as a reference unit and the central concern with environmental sustainability. With 
regard to the protagonism of actors and their political participation, the issue of participation and autonomy of women and youth and inequalities in social relations between men and women has gained strength in the debates on rural development.

\subsection{Social capital in the territory}

To analyze the rural development of the territory - the long-term social changes - it is essential to understand the evolution of its social capital (BEBBINGTON, 2005). In this study, we work with the hypothesis that the effects of public policies were enhanced because there is a long-term process in the territory of strengthening farmers' organizations and advisory entities (non-governmental organizations).

During the military dictatorship, the Ecclesiastical Base Communities (CEBs), linked to the Liberation Theology of the Catholic Church, played a fundamental role in the formation of social capital in the territory. Following the theoretical perspective of Bebbington (2005), it is possible to affirm that during the 70s and 80s, the actions of the CEBs strengthened the community (or union) social capital, both by encouraging practices to improve the feeding conditions of families, as well as community seed banks, collective gardens or manioc flour production sheds, as promoting political formation in communities when, in the light of the gospel, the forms of oligarchy domination over poor peasants were discussed, revealing these mechanisms as injustices and social constructions, and not as a fatality, because "God wants it that way". The CEBs carried out the political mobilization work that, as proposed by Bourdieu (1996), converts the existence of the class in theory into existence in practice. In this case, the class of poor peasants, exploited by the oligarchies - the colonels - who controlled the land and the local political power. According to the author, the political mobilization has the objective of seeing the class satisfied and mobilized, as a result of the classification struggle as a symbolic and political struggle to impose a social worldview.

This political mobilization resulted in the formation or strengthening of community associations and in the feeling of belonging to communities - the strength of the idea of community to this day demonstrates the importance of the work led by the CEBs. It also resulted in the strengthening of what Bebbington (2005) calls social capital as a bridge, when it helped the peasants to organize themselves and question the directions of the rural workers' unions linked to local powers and which, therefore, did not support the mobilizations coming from the communities and the claims that these addressed to governments. From the mid-1980s onwards, in several municipalities in the territory, organized workers from the communities where the CEBs worked took over the rural workers' unions.

With the re-democratization, Non-Governmental Organizations (NGOs), such as the IRPAA, founded by Dom José Rodrigues, the famous bishop of Juazeiro, tied to the Liberation Theology and a great reference for peasant mobilizations in the 70s and 80s, emerged; and SASOP, an entity originating from the Alternative Technologies Project (PTA-FASE), which started to work in partnership with farmers' organizations and CEBs. More recently, in 2003, SAJUC was founded. The work of these and other NGOs contributed to the intensification of exchanges between communities, given the mobility of their staff and, subsequently, to the formation of social capital "on the ladder" (BEBBINGTON, 2005), with the construction of public policies and formal spaces for social participation in its formulation and monitoring. 
As Bebbington (2005) notes, social capital has a value in itself, by promoting spaces for social participation and empowerment (political voice), and it also has an instrumental value, as it facilitates access to other material resources, such as infrastructure, or non-material resources, such as information and knowledge.

\section{ECONOMIC-ECOLOGICAL ANALYSIS OF THE AGROECOSYSTEMS OF THE TERRITORY}

In this section, we will make a brief trip to the places of life and work of five peasant families in the territory. The first three in Juazeiro and Casa Nova and, after a break, we go to Campo Alegre de Lourdes and Remanso.

\subsection{Agroecosystems in Juazeiro and Casa Nova: three peasant families}

Re. (27 years old) and Mr. Le. (39) got married in 2008, live in the Olhos d'Água community, in the rural area of Juazeiro, and since 2010 they have lived on the property. The electricity network of the Luz para Todos (Light for All) program reached the community only in 2018. Before this, they used solar panels installed in 2007. For 10 years, from 2009 to 2019, Le. provided services as an autonomous driver of students of public schools. The couple raises goats and sheep, which access a large area of community Pasture. The theme of the rights of traditional fundo de pasto communities is discussed in the community with advice from the IRPAA, which resulted in a visit by the Secretariat for the Promotion of Racial Equality (Sepromi) of the government of the state of Bahia in 2019, to initiate the process of certification as a traditional fundo de pasto community. Through the Cabra Forte Program, also in the state, a community artesian well was built in 2005, very close to the couple's residence. In 2013, Le. accessed credit from Banco do Nordeste for the construction of a $110 \mathrm{~m}^{3}$ reservoir. During the prolonged drought from 2011 to 2015 , the Pronaf credit was used for drought and crop insurance, policies that combine the social, assistance and agricultural frameworks. As of 2016, they began to actively participate in the activities of the Pró-Semiárido program: workshops, learning groups and joint efforts. As part of the program, a chicken barn and screened economic beds for the production of vegetables were built with non-refundable resources. For two years (2017 and 2018), like other families in the community, Le. dedicated himself to growing tomatoes in an agrochemical system. Re. reports that it was a very difficult moment, as the demand for work was intense, there was a lot of exposure to pesticides and the economic risks associated with a crop with a high consumption of external inputs and uncertain prices at the time of sale generated a lot of tension between the couple. In the quantitative study, an economic analysis of two subsystems was carried out for one year (February 2018 to January 2019): goats and sheep, and tomato clearing. As it rained a lot, there was a high production of goat and sheep meat for sale in local markets (1,650 kg), for family consumption and donations, in addition to the formation of a stock of animals in the period (equivalent to BRL $17,000.00^{\circ}$ ). The subsystem of raising sheep and goats occupied 657 hours of work in the year and generated a monetary income of BRL 21,320.00 (production costs totaled BRL 1,930.00). The tomato farm occupied 768 hours of work for the couple in the year and generated monetary income of BRL 12,105.50, as the production costs were very high with payment for services, purchase of irrigation equipment, seedlings, synthetic fertilizers and pesticides (BRL

\footnotetext{
${ }^{9}$ At the time of the field research, US\$1.00 = BRL 4.00.
} 
14,984.50) - Graph 1. Since 2018, the family has decided not to plant conventional tomato gardens anymore. The training activities indicated the need to invest more in the production of forage for chickens and for goats and sheep, which should be stored for the dry season, which is possible due to the good availability of water. With the pasture, meat production is high in good winter years. There are good prospects for increasing the production of vegetables and chicken and eggs, which are well accepted in the local market, such as the Juremal district, the urban area closest to the community.

Graph 1 - Composition of monetary rural income and productive costs of the agroecosystem managed by Re. and Le. from February 2018 to January 2019. Olhos d'Água, Juazeiro, Bahia

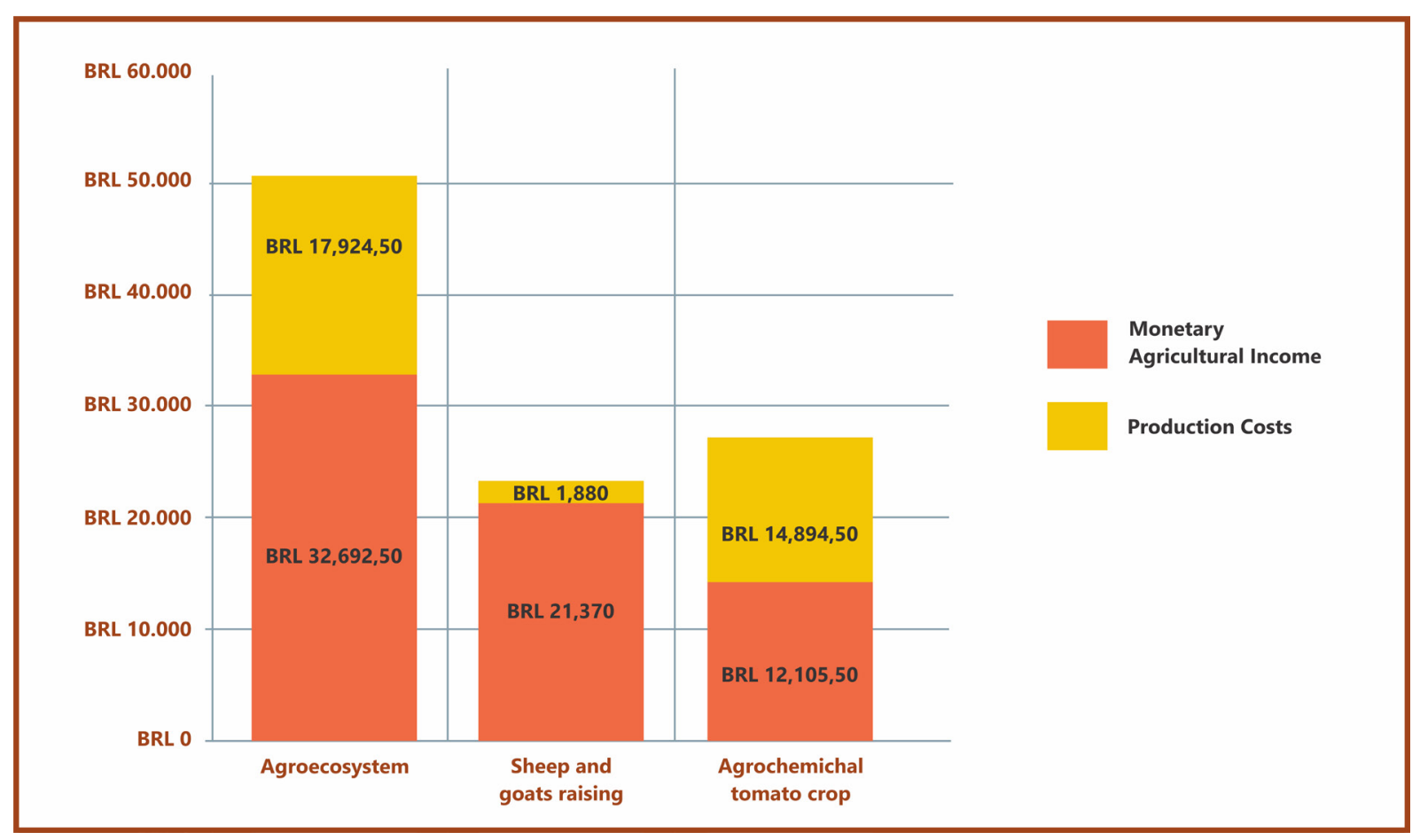

Source: Field research.

Mr. Gl. is 62 years old and has been receiving rural retirement for two years. He is married to Jo. (59), a farmer, seamstress and school cook at a rural municipal school. They live with one of their daughters, G. (31), in the Budinho community, a rural area in the municipality of Casa Nova. The other children live in the city, in Casa Nova and Petrolina-PE. The property, inherited from Mr. Gl. father, increased with the acquisition of a parcel of land in 2010. It has two 16,000-liter cisterns built in 2004 and 2008 by the One Million Cisterns Program, executed by the Articulação Semiárido Brasileiro (ASA), one of them located in the house of the son who no longer lives on the property, being used as a sewing studio by Jo. In 2012, the electricity network reached the community through the Luz para Todos Program. Through Pronaf B, using Embrapa Semiárido and Pró-Semiárido resources, the family opened two clay pits (2015 and 2019), surrounded a part of the property, built a flood cistern, with a capacity of 52,000 liters, and economic planting beds covered with screens. With their own resources, they acquired a forage machine and recently expanded, from 2016, the flock of sheep. After participating in courses given by Embrapa, the family started to make silage with the available forage. They reported high production of corn and beans in 2017. 
Mr. Gl. and Jo. participate in the community association Sítio Novo Socorro. Most of the family's monetary income comes from Jo.'s rural social security and non-agricultural activities. In the period analyzed (October 2018 to September 2019), the monetary agricultural income was BRL 2,898.00. However, the production destined for family consumption (equivalent to BRL $2,733.00$ ) and for donations (BRL 3,500.00), which are mainly intended for children living in the urban area, is significant. The family reports the production of more than 300 bunches of collard greens and 500 of coriander, as well as a great diversity of medicinal plants. These data reinforce the importance of having multiple activities and retirement so that the family remains in the rural area producing food for local consumption, contributing to the promotion of food and nutritional security in the territory.

$\mathrm{Cl}$. is 53 years old. She lives in the district of Massaroca, in Juazeiro. In 1987, the committee of the Massaroca agricultural community associations was created, in 1990 the Rural School was founded and in 2012, with the support of IRPAA, a fruit processing unit was built. Massaroca is known in the territory for the strong mobilization that originates in CEBs. In 2009, Cl. decided to expand her residence, which she did with her own resources. In the same year, her mother moved in with her, which allowed her to participate more in the organizational processes of the territory. This intense participation in the last ten years, which contributed to the economic results that will be presented below, can be verified by the qualitative analysis of the index of the attribute "social integration", whose index varied from 0.44 in 2009, to 0.80 in 2019 (graph 2).

Graph 2 - Evolution of the social integration index for the agro-ecosystem managed by Cl.'s family from 2009 to 2019. Massaroca, Juazeiro, Bahia. Scores from 1 to 5 were assigned to each parameter analyzed (very low, low, moderate, very high and high)

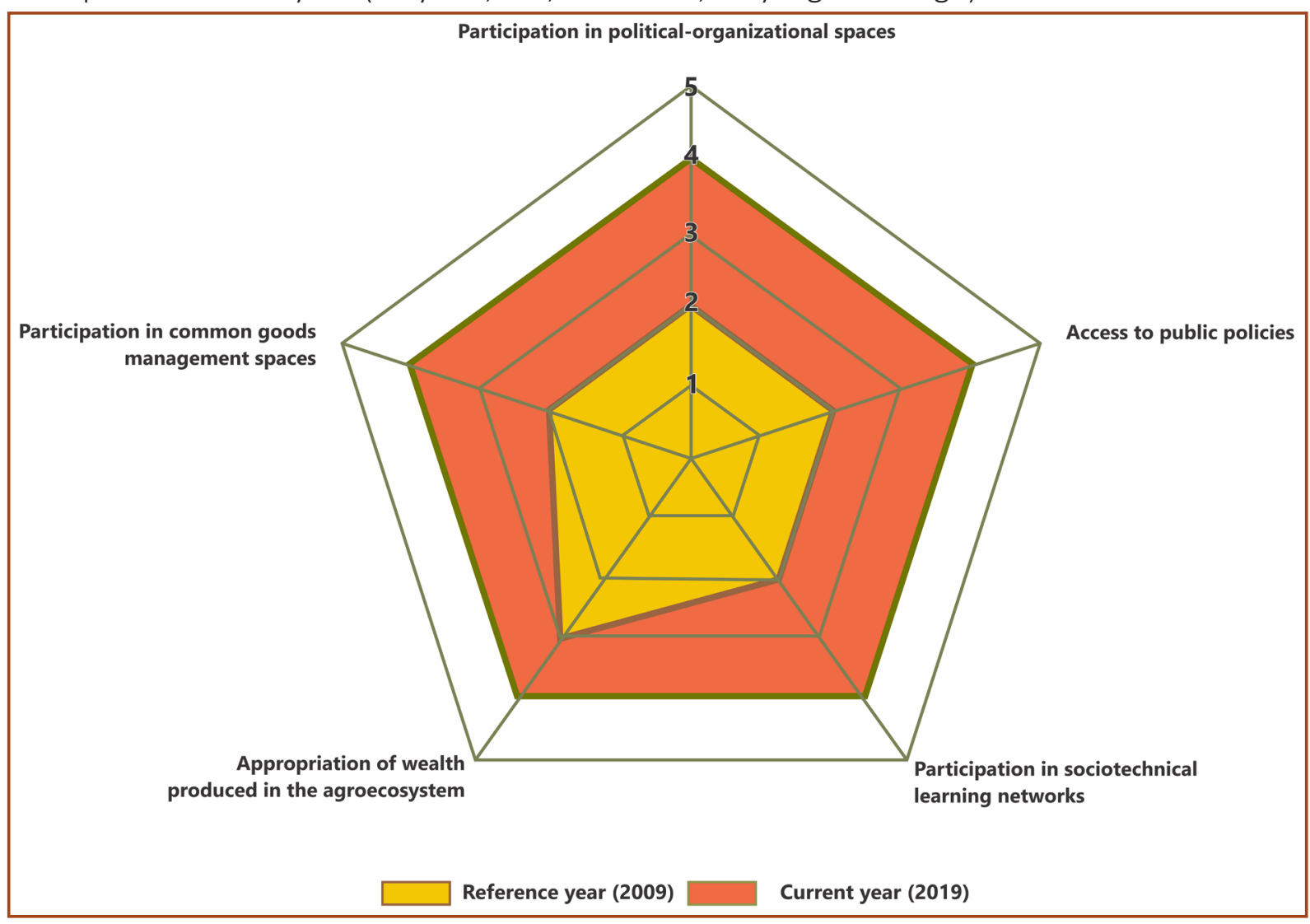

Source: Field research. 
The family built consumption and production cisterns, accessed Pronaf B through Banco do Nordeste to build clay pits and buy forage machines. With resources from the Brasil sem Miséria Program, Cl. received technical advice and implanted a forage palm field in 2014, the same year that she bought a motorcycle with the sale of vegetables, facilitating her participation in social and political activities. Cl.'s husband has serious back problems and so he devotes little time to work in the agroecosystem, as well as the couple's two children who work as masons.

One of the results of Cl.'s dedication to work in the agroecosystem is the agricultural income of approximately BRL 29,000.00, which represents more than $50 \%$ of the total family income, of which almost BRL 17,000.00 is monetary income, measured in the period February 2018 to January 2019. In addition, this year it produced a stock of goats and sheep of around BRL 7,000.00. The rearing of chicken, for which $\mathrm{Cl}$. dedicated 200 hours of work in the year under analysis, the raising of goats and sheep, and the cultivation of vegetables, account for most of the added value for family work in the period (graph 3). As an example, 634 dozen eggs and about 690 bunches of coriander were produced, highlighting the importance of peasant agriculture for the food and nutritional security of the territory and local markets for the generation of income for rural families.

Graph 3 - Added value and intermediate consumption of the agroecosystem managed by $\mathrm{Cl}$. from February 2018 to January 2019. Massaroca, Juazeiro, Bahia

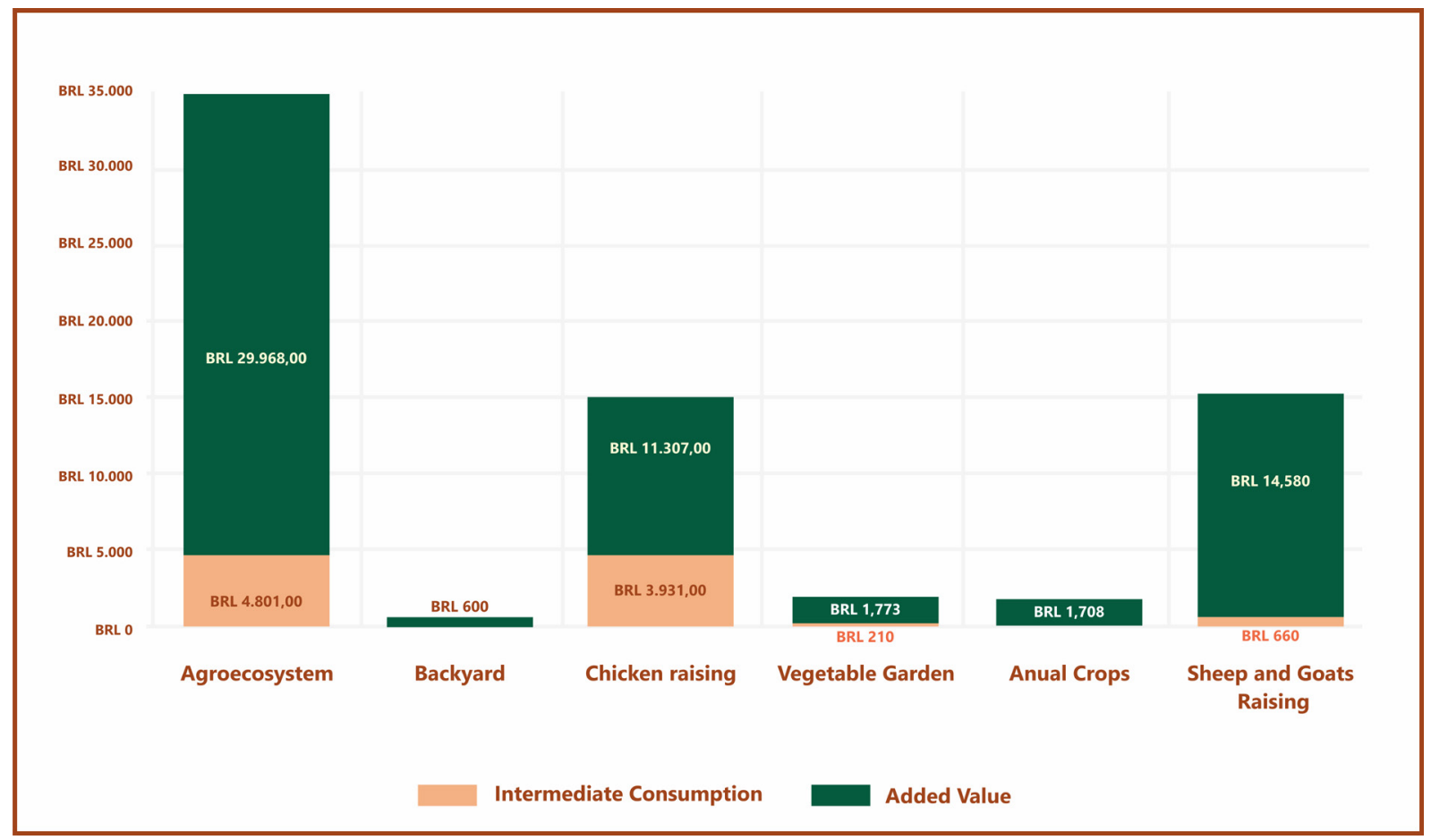

Source: Field research.

\subsection{A pause in the journey: recognizing relations between rural and urban in the territorial plot}

We now pause briefly in describing the trajectories and experiences of the families before moving on to Remanso and Campo Alegre de Lourdes.

Juazeiro and Petrolina are the two largest cities in the region, where many public services and bank branches are located, commerce is busier, neighborhoods on the outskirts are large. 
Many irrigated perimeter projects are located in the territories of these two municipalities. There are billboards and equipment and chemical input stores for conventional irrigated production. To get to Casa Nova, leaving Juazeiro, you need to cross the bridge and go through Petrolina, and then enter Bahia again on the road on the banks of the São Francisco. It is about $70 \mathrm{~km}$ from Petrolina and Casa Nova. The agriculture of Casa Nova also has a great influence of these socio-technical networks of agribusiness, especially in the communities closer to the urban area of the municipality and the Sobradinho lake dam. As we have seen in the cases described, access to credit (Pronaf) by farming families via Banco do Nordeste is very common.

Being closer to urban areas makes the use of non-agricultural work in urban centers recurrent for many rural families, characterized by multiple activities, as we have seen in the cases described above. Another aspect of this territorial plot, to use a term by Favareto et al. (2015), which strongly marks the trajectory of families are the proximity markets, door-to-door sales, small businesses in the districts and peripheral neighborhoods, restaurants, "producer" markets and very busy fairs. To understand rural development, it is necessary to pay attention to these markets, which are often nested markets (PLOEG, 2011), which depend on reciprocal relationships between farmers and small traders or directly with consumers.

As in other municipalities, it is also very important, in order to understand rural development, to pay attention to the struggles for recognition of traditional fundo de pasto communities, since they are vast portions of the territory accessed by the communities. If access to these lands of traditional community use were governed by the rationality of the land as a commodity and by the logic of completely fenced off individual property, these social management practices would be rendered unfeasible, compromising the socioeconomic reproduction of thousands of rural families and generating enormous negative impacts for the production of food for the territory and for the local culture.

Remanso and Campo Alegre de Lourdes are less populous municipalities than Juazeiro and Casa Nova and suffer much less influence from the socio-technical networks of agribusiness in irrigated areas. In addition to the less agitated climate of the smaller urban centers, different types of relationship between the rural and the urban, different from the signs of agricultural modernization, are perceived when walking through the urban areas of these municipalities: cars passing by loaded with fodder, motorcycles with gallons of milk, specialized honey trade, forage machines displayed in front of the stores, machines coming and going and workers asphalting highways, the open suitcases of cars to display goat cheese, vegetables and fruits that come from the farm on the outskirts of the markets.

\subsection{Campo Alegre de Lourdes and Remanso: stories about another two peasant families}

Mr. Re. (44) and I. (43) live in the Travessão community, in Campo Alegre de Lourdes. T., the youngest daughter, is 20 years old and lives with her parents, and Ta., the oldest, has been studying since 2015 at the Federal University of Vale do São Francisco in São Raimundo Nonato, Piauí.

In 2006, the family started to participate in the Rural Workers Union of Campo Alegre de Lourdes, and since 2007, they have been systematically assisted by SASOP, through the direct execution of federal and state technical assistance public policy projects (ATER). In this period (2007 to 2019), the family incorporated a series of innovations in the agroecosystem, made possible by the three generations of public policies for family agriculture (GRISA; SCHNEIDER, 2015). According to Araújo et al. (2019): 
Re. and I. accessed several policies, from the three generations. From the first generation, the Pronaf credit, used for the construction of the first cistern, in 2001 and the crop insurance (2009 to 2015). From the second generation, the social policies, in 2002, and from 2004 to 2012. Since 2003, the policies of the third generation have become very relevant, which have as reference the construction of markets for food and nutritional security and sustainability, driven by the Zero Hunger program and the National Council for Food and Nutritional Security (CONSEA). In 2012 and 2013, the family participated in actions of the programs for living with the semiarid coordinated by the Brazilian Semi-Arid Articulation (ASA): the One Million Cisterns (P1MC) and One Land and Two Waters (P1 + 2) Programs. Since 2017, they have participated in the Pró-Semiárido Program, which provides technical advice, exchanges and access to infrastructure and equipment. Two other public policies benefited the family, the Cabra Forte project, from the government of the State of Bahia, which enabled the construction of the community artesian well in 2001, and Luz para Todos, a federal program that guaranteed the community access to electricity in 2007. (ARAÚJO et al., 2019, p. 3, translated from Portuguese).

The family, at the time of the field research (2019), used an area of about 100 hectares and organized production in six subsystems: sheep, cattle, pigs, backyards, bees and annual crops.

The autonomy index varied in the period (2007 to 2019), from 0.74 to 0.87 , due to the positive evolution of the parameters associated with the family's self-controlled resource base (graph 4).

Graph 4 - Evolution of the autonomy index for the agroecosystem managed by the Re. and I. family from 2007 to 2019. The parameters on the right, in blue letters (food self-supply to equipment/infrastructure) refer to the self-controlled resource base. On the left, marketable productive resources. Travessão, Campo Alegre de Lourdes, Bahia

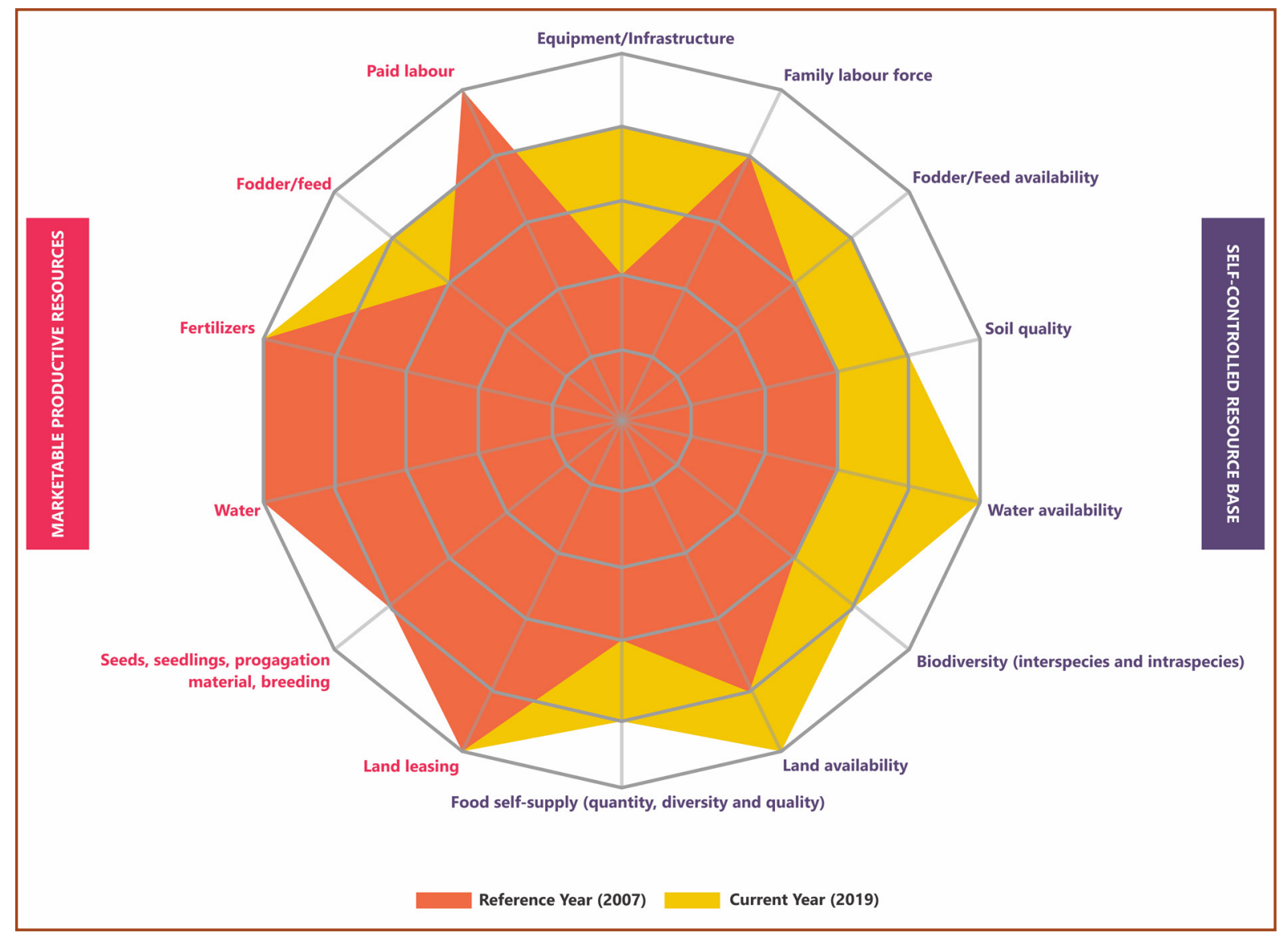

Source: Field research. 
In addition to the improvement of water storage infrastructures and the expansion of land capital, the acquisition of machinery and equipment that intensified the flows between subsystems and the diversification of production, including the beginning of beekeeping, in 2015, were responsible for this increase (ARAÚJO et al., 2019).

During the period of quantitative analysis (October 2018 to September 2019), the family produced 25 items and generated a monetary income of BRL 18,327.00 (productive costs of BRL $7,383.00$ ) and a self-consumption gross product of BRL 14,700.00, in addition to having stored the equivalent of BRL 5,000.00 (graph 5). Monetary income came from the sale of honey, cattle and corn and watermelon fields. For beekeeping, they dedicated approximately 500 hours of work and produced $1,110 \mathrm{~kg}$ of honey. The agroecosystem generated a monetary profitability of 2.48, which means that for every BRL 1.00 invested (purchase of inputs or payment for services), there was a return of BRL 2.48. The commercialization index (from zero to one) was 0.47 , due to the use of own resources and the low consumption of external inputs (Graph 6).

Graph 5 - Distribution of generated income (monetary, self-consumption, donations and stocks) by the aggregate of the agroecosystem production managed by Re. and I. between October 2018 and September 2019

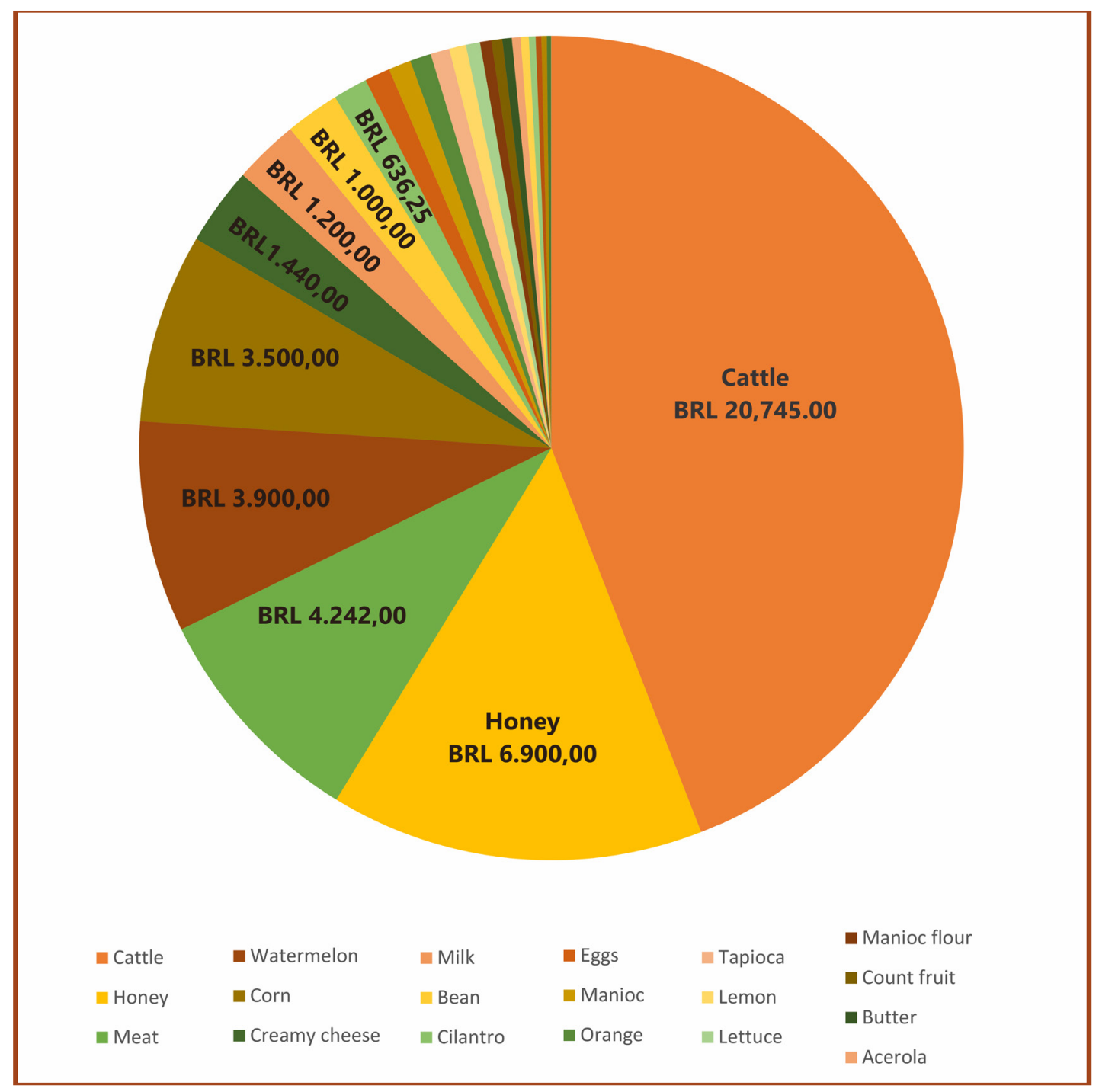

Source: Field research. 
Graph 6 - Synthesis diagram of the agroecosystem managed by Re. and I. Travessão Community, Campo Alegre de Lourdes, Bahia

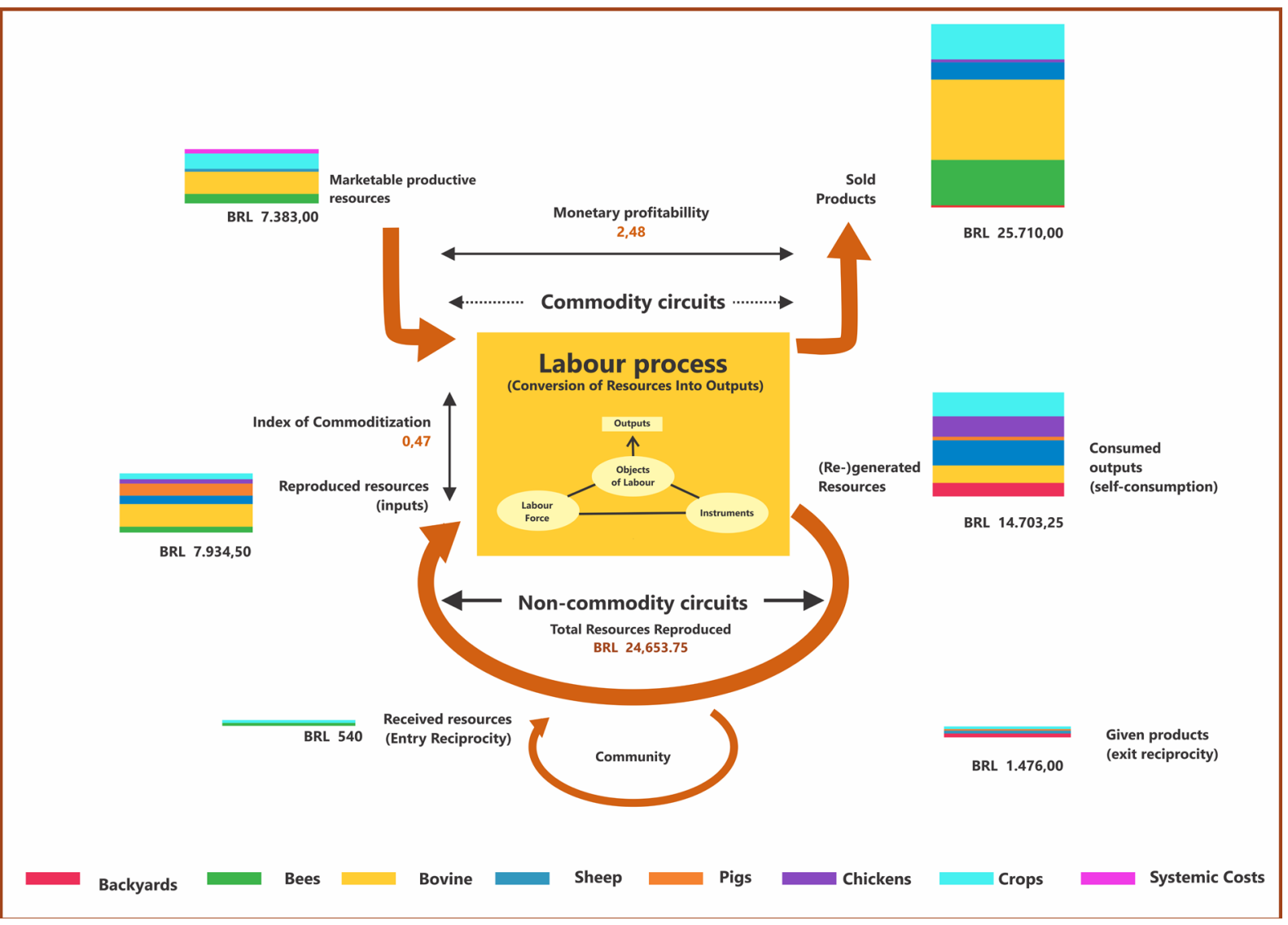

Source: Data: field research. Scheme by Ploeg (2008).

IV. is 51 years old. She lives with her mother, Dona N. (71), who is retired, and with her sons C. (25) and D. (27) on the family property in the Negros community, in Remanso. Iv. lived in São Paulo from 1987 to 1998, when she returned to live with her mother. Iv. built her own home in 2006, where her mother went to live in 2013. The community received the electricity grid in 2007, through the Luz para Todos Program, and the nearest main road was paved in 2019.

Dona N. began participating in the community association in 1996. In 1998, she participated in an exchange in Piauí, where she brought the first leucena seedlings. N. and Iv. recall that they have been interacting with SASOP teams since 2002. Currently, they receive advice from IRPAA through the Pró-Semiárido program. In 2004, Iv. participated in the activities of the One Million Cisterns Program, run by ASA. In 2017, the family drilled an artesian well and a clay pit-trench. In 2018, they were awarded a beekeeping kit and the community received a forage machine through the Pró-Semiárido program. Iv. worked out of the farm for a few months in 2016 and 2018, and C. also migrated to the Midwest for a while. However, they maintained investments in the property, and in this year 2019, all members of the family dedicated themselves fully to the management of the agroecosystem.

IV. has been a beekeeper since 2004. Since 2007, she sells honey to Rei do Mel, a local merchant.

As of 2016, with the involvement in the Pró-Semiárido program, and with the opening of the well in 2017, the family started to increase and diversify production. They intensified the production of seedlings, especially of forage species, with leucena being the most used, in addition 
to palm and grasses. They built the chicken barn and intensified production around the house. After increasing forage production, C. accessed, in 2017, credit for the purchase of sheep. One of the family's strategies is to sell seedlings and leucena silage. At the end of the rainy season, they invested in forage stock for the animals. The economic data for the period from October 2018 to September 2019, shown in Graph 7, demonstrate the results of this strategy. The family produced an agricultural income of BRL 9,782.50 (monetary income of BRL 5,630.00).

The family property has many areas of preserved caatinga and great biodiversity of plants, insects and birds. The great diversity of healthy food production, a large part donated to relatives and neighbors, contributes to the promotion of food and nutritional security for the family of Iv. and other families in the territory, and returns due to reciprocity in some tasks. Dona $\mathrm{N}$. retirement guarantees a stable base of financial resources, contributing to the permanence of this family in the community, producing food and caring for biodiversity.

Graph 7 - Diversity of income sources obtained from the production of the agroecosystem managed by IV. and family, considering sales, self-consumption, donations and stock, from October 2018 to September 2019. Comunidade Negros, Remanso, Bahia

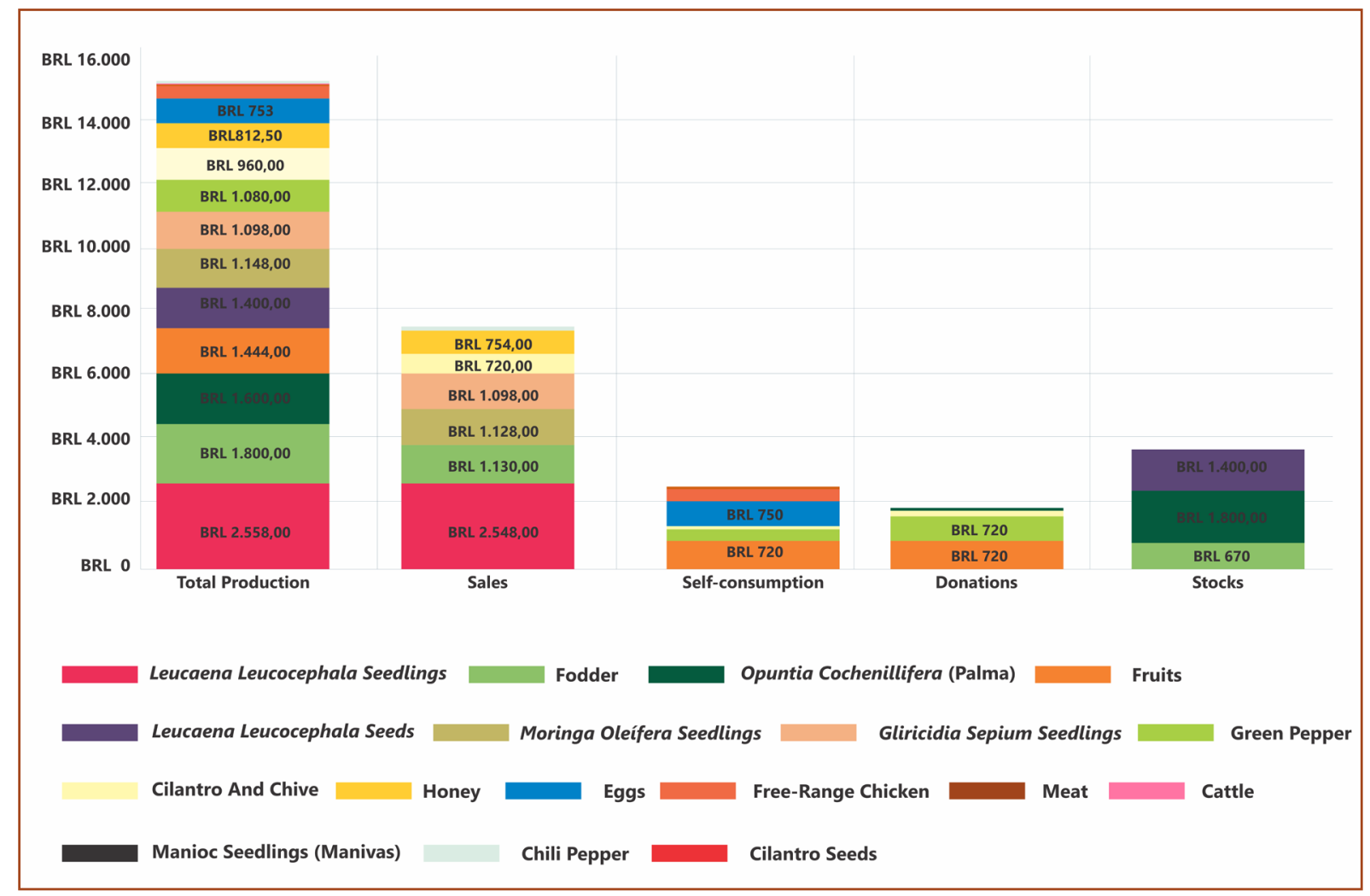

Source: Field research.

\section{INTERPRETING CHANGES IN THE TERRITORY: AN ANALYSIS BASED ON THE TRAJECTORY OF THE FAMILIES}

Even though it is a small sample, the diversity of the strategies of the five families and the different economic results in the analyzed period shows that there is a great and relevant heterogeneity of agricultural trajectories with the rural development processes. 
In this sense, each agroecosystem will always be a particular case. However, we believe that are not exceptions cases of families that have achieved greater levels of autonomy, satisfactory economic results, with agricultural incomes guaranteeing good living conditions, greater social integration that results in the increasing incorporation of innovations, significant improvement in infrastructures available in agroecosystems and communities, greater security to invest with the income from social policies, and increased and diversified production that contribute to the food and nutritional security of the territory.

This reinforces our argument that the five cases described here are not exceptional, the fact that some public policies that affected the Brazilian semi-arid region in the last 25 years reached a very large number of families in the territory of the Sertão do São Francisco, expanding the capacity to action by non-governmental organizations that already operated in this territory, providing communities and families with better infrastructure and diversifying their knowledge repertoires. It is worth mentioning examples of very comprehensive policies, not focused on a few families in each community, such as the most recent Pró-Semiárido program, in addition to the federal and state public policies of technical rural assistance (ATER), the P1MC and the One Land and Two Waters Program (P1+2), all carried out by non-governmental organizations. It is also necessary to consider, in this list of comprehensive policies, the expansion of the scope of rural retirement, income transfer policies and the Luz para Todos Program.

Between the end of 2019 and the beginning of 2020, we have followed the preliminary results of studies with other families using the methodological procedures described in this article and accessed reports and documentaries that portray many experiences in the territory. They have seen many innovations in different fields, some of which did not appear in the five cases reported here, such as the community organization for the marketing of honey, the sale of vegetables, fruits and flour to the National School Meals Program (PNAE), the agro-industrialization of umbu and other fruits that are sold to markets in large urban centers, the production and marketing of goat cheese, the organization of groups of young people to commercialize production. Other families are even more advanced in the autonomy of the production of fodder for goats and sheep and, even in smaller areas than the families directly involved in this research, they sell live animals and meat in local markets.

Thus, we present the hypothesis, to be investigated in future research, that the analysis of the trajectories of these five families - their life strategies (BEBBINGTON, 2005), helps us to understand why there was a significant reduction of poverty in this territory, and in all the semiarid region, since the mid-1980s, which has occurred more quickly and effectively since the 2000s. In fact, long-term changes are very significant. ASA pointed out that no human life was lost due to the effects of the last major drought, which occurred between 2011 and 2016. In the drought between 1979 and 1983, it is estimated that more than 700 thousand people (some estimate more than 1 million), most of them children, died of causes associated with the effects of drought (CPT; CEPAC; IBASE s.d.). In 1999, Aziz Ab'Saber drew attention to the hunger and misery of huge contingents in the semiarid region, which suffered the effects of the drought that lasted from 1996 to 1999, and pointed out solutions based on the understanding of the ecological and social dynamics of this immense territory (AB'SABER, 1999). Although it was an incomparably less drama than during the military dictatorship, there were still many fatal victims in this calamity at the end of the 20th century. In the times between the three droughts, the ideas, institutions and interests at stake changed significantly. According to this approach discussed by Bonnal; 
Delgado; Cazella (2011), the negotiation processes between the actors must be understood as resulting from the complex interaction between the diversity of ideas related to the interests at stake and to the existing institutions or those under construction (the three "Is").

The public policies that affected the territory combined two approaches that for a long time were seen as exclusionary in programs to fight poverty: the emphasis on the material conditions of families, such as the infrastructure mobilized for production (the emphasis on what the poor do not have), and changes in institutions and the strengthening of social capital - the political economy and, therefore, the unequal power relations (BEBBINGTON, 2005).

The policies promoted synergies between the different assets of the communities. The programs for living with the semi-arid - One Million Cisterns (P1MC) and One Land and Two Waters $(P 1+2)$, carried out by ASA organizations in partnership with the federal government, made the construction of infrastructures - water cisterns on a large scale 16,000 liters to store water for drinking and cooking, stone tanks, clay pit barriers or 52,000-liter floodwater cisterns to store water to irrigate crops or for animals to drink. But infrastructures, which have greatly improved the ecological capital of agroecosystems managed by families, by making water storage feasible, are only part of the programs, which invest in training and mobilizing communities by promoting courses and exchanges on water management, enriching the knowledge of families and community organization - strengthening, at the same time, ecological, human and social capital (BEBBINGTON, 2005).

Other more recent public programs, such as the Pró-Semiárido program, also combine direct material support, for example by financing families and communities, with non-refundable resources, to purchase material for beekeeping, forage machines for community use, material for construction of garden beds and screened nurseries and for the expansion of aviaries, with training and exchange processes, such as learning groups and joint efforts. Several infrastructures made possible by the program were built in joint efforts, remembered by families as happy and relaxed moments.

The recognition of the rights of traditional fundo de pasto communities is the result of very significant changes in institutions, such as greater attention of advisory entities to the social dynamics that govern access and use of community pastures, including the constitution of specialized legal advice to communities, as well as official recognition in the Constitution of the State of Bahia and, at the federal level, Decree $6040 / 2007^{10}$, that recognizes the rights of traditional communities to territories, including fundo de pasto communities. But these changes in government institutions would not have happened without the strengthening of the community social capital provided by the work of CEBs and advisory NGOs.

More recently, a topic that has mobilized community and advisory organizations in the territory are the unequal relations between men and women, especially with regard to the division of domestic work and decisions about the distribution of wealth generated by the work of families. Based on the visibility of the overload of women's work and the income generated by agricultural production and by women's non-agricultural activities, this topic has been discussed in training spaces in communities and in the territory. It is women who, in NGOs and or in government

\footnotetext{
${ }^{10}$ Decree 6040/2007 instituted the National Policy for the Sustainable Development of Traditional Peoples and Communities. It defines traditional peoples and communities as "culturally differentiated groups that recognize themselves as such, have their own forms of social organization, occupy and use territories and natural resources as a condition for their cultural, social, religious, ancestral and economic reproduction, using knowledge, innovations and practices generated and transmitted by tradition". Traditional territories are defined as "the spaces necessary for the cultural, social and economic reproduction of traditional peoples and communities, whether they are used permanently or temporarily" (SANTILLI, 2009).
} 
agencies, have been questioning the organizational culture that makes women's work invisible and does not question the traditional practices of sexual division of labor that generate overload for women farmers. They are movements that pressure institutions, including community ones, for changes in the social rules that govern them. The economic results presented in surveys with families using the Lume method can contribute to shedding light on these topics.

Two key ideas that were built with great social and political density and were able to guide the actions of a wide range of institutions in the territory were those of "Coexistence with the Semi-Arid", mobilized by ASA as of the end of the 90s and that guided, as witnessed, comprehensive public programs; and the motto of traditional pasture communities: "Our way of living in the sertão", which refers to the rights of communities to territories and their ways of life and to traditional practices related mainly to the rearing of goats and sheep.

Ideas influence the practices of individuals, including their engagement in social processes that create or modify organizations capable of forming coalitions that change institutions. To understand the rural development of the Sertão do São Francisco territory, it is necessary to be aware of

[...] a conception in which the beliefs, ideologies and ideas that channel the conflicting interests of individuals - like switches that change the direction of the railway and determine the direction of a train, in Weber's well-known metaphor - are not something given but something that can be explained, understood and, therefore, takes place in the structure of causal nexuses of development processes. (FAVARETO et al., 2015. p. 29, translated from Portuguese).

These significant changes over the past 40 years, from the beginning of the tragic drought in 1979 to the present, are largely explained by the surprising results of the public policies of the three generations (GRISA; SCHNEIDER, 2015) that affected the territory, guided by agrarian and agricultural, social and assistance references, and building markets for food security and sustainability. The results are surprising because often, due to the synergistic combinations between policies promoted by families and advisors, they go far beyond what the policy makers imagined, when families use them to increase their autonomy, expanding the self-controlled resource base and strengthening their strategies. This is the case with social policies, such as retirement and income transfer programs, which promote more freedom and security for families to invest in food production.

Following the point of view of Bonnal, Delgado and Cazella (2011), we hypothesized that, in the Sertão do São Francisco, public policies and institutions created recently to guide territorial development were used by the different social actors identified with the historical mobilizations of the peasantry to expand the scope of ideas and the scale of experiments that allowed them to "try to build a strategic rural development proposal for the territory, used to build a kind of 'hegemonic cluster' or strategic coalition".

Ploeg (2011) notes that rural development practices, by promoting multifunctionality, constitute important lines of defense for food production. This is what we see in the Sertão do São Francisco territory. The trajectories of the families analyzed here show how the production of food for self-consumption by families, to feed reciprocity relations with donations and exchanges and for commercialization in a wide variety of markets in the territory, while strengthening the struggle of families for autonomy, contributes to gather active social forces in the construction of guided rural development alternatives, in opposition to the model of subordination to agrochemical packages, through the strengthening of peasant agriculture and the food sovereignty of the territory. 


\section{REFERENCES}

AB'SABER, Aziz. Sertões e sertanejos: uma geografia humana sofrida. Estudos Avançados, Dossiê Nordeste Seco, São Paulo, v. 13, n. 36, p. 7-59, May/Aug. 1999.

ARAÚJO, Eduardo Rodrigues; MONTEIRO, Denis; LIMA, Gildete Pereira; LEITE, Carlos Eduardo Oliveira de Souza. Análise das estratégias reprodutivas camponesas na construção da autonomia de um agroecossistema em Campo Alegre de Lourdes, semiárido baiano. Revista Cadernos de Agroecologia, São Cristóvão, Sergipe, v. 13, n. 2, Dec. 2019.

BEBBINGTON, Anthony. Estrategias de vida y estrategias de intervención: el capital social y los programas de superación de la pobreza. In: ARRAIGADA, Irma (Org.). Aprender de la experiencia: el capital social en la superación de la pobreza. Santiago: CEPAL, 2005. p. 21-46.

BONNAL, Philipe; DELGADO, Nelson; CAZELLA, Ademir Antônio. Subsídios metodológicos ao estudo do desenvolvimento territorial rural. In: MIRANDA, Carlos; TIBURCIO, Breno (Org.). Políticas públicas, atores sociais e desenvolvimento territorial no Brasil. Brasília: IICA, 2011. (Série Desenvolvimento rural sustentável, v. 14). p. 35-60.

BOURDIEU, Pierre. Razões práticas: sobre a teoria da ação. Campinas: Papirus, 1996.

CAZELLA, Ademir A.; BONNAL, Philipe; MALUF, Renato S. Multifuncionalidade da agricultura familiar no Brasil e o enfoque da pesquisa. In: CAZELLA, Ademir A.; BONNAL, Philipe; MALUF, Renato S. (Org.). Agricultura familiar - multifuncionalidade e desenvolvimento territorial no Brasil. Rio de Janeiro: Ed. Mauad. 2009. p. 47-70.

CPT, CEPAC, IBASE. O genocídio do Nordeste 1979-1983. São Paulo: Ed. Mandacaru, [s.d].

FAVARETO, Arilson; KLEEB, Suzana; GALVANESE, Carolina; MAGALHÃES, Clarissa; MORALEZ, Rafael; SEIFER, Paulo; BUZATO, Heide; CARDOSO, Ricardo et al. Territórios importam: bases conceituais para uma abordagem relacional do desenvolvimento das regiões rurais ou interioranas no Brasil. Revista em Gestão, Inovação e Sustentabilidade, Brasília, v. 1, p. 14-46, 2015.

GRISA, Cátia; SCHNEIDER, Sérgio. Três gerações de políticas públicas para a agricultura familiar e formas de interação entre sociedade e Estado no Brasil. In: GRISA, Catia; SCHNEIDER, Sergio (Org.). Políticas públicas de desenvolvimento rural no Brasil. Porto Alegre: Editora da UFRGS, 2015. p. 19-52.

PETERSEN, Paulo; SILVEIRA, Luciano Marçal da; FERNANDES, Gabriel Bianconi; ALMEIDA, Sílvio Gomes P. Método de análise econômico-ecológica de agroecossistemas. Rio de Janeiro: AS-PTA, 2017.

PLOEG, Jan Dowe van der. Camponeses e a arte da agricultura: um manifesto Chayanoviano. São Paulo; Porto Alegre: Editora UNESP; Editora UFRGS, 2016.

PLOEG, Jan Dowe van der. Trajetórias do desenvolvimento rural: pesquisa comparativa internacional. Sociologias, Porto Alegre, ano 13, n. 27, p. 114-40. May/Aug. 2011.

PLOEG, Jan Dowe van der. Camponeses e impérios alimentares: lutas por autonomia e sustentabilidade na era da globalização. Porto Alegre: Editora da UFRGS, 2008. 
SANTILLI, Juliana Agrobiodiversidade e direitos dos agricultores. São Paulo: Peirópolis, 2009.

SCHNEIDER, Sergio. Situando o desenvolvimento rural no Brasil: o contexto e as questões em debate. Revista de Economia Política, São Paulo, v. 30, n. 3 (119), Jul./Dec. 2010. p. 511-31.

SCHNEIDER, Sergio. A abordagem territorial do desenvolvimento rural e suas articulações externas. Sociologias, Porto Alegre, ano 6, n. 11, p. 88-125, Jan./Jun. 2004.

\section{About the authors:}

Denis Monteiro: Doctorate in Science, Technology, and Innovation in Agriculture from the Federal Rural University of Rio de Janeiro (UFRRJ). Agronomist by the UFRRJ. Executive secretary of the National Articulation of Agroecology. Technical advisor to AS-PTA Family Agriculture and Agroecology. E-mail: denisagroecologia@gmail.com, Orcid: http://orcid.org/0000-0003-4460-4853

Cezar Augusto Miranda Guedes: Post-doctorate from the Technical University of Lisbon (UTL). Doctorate in Business Administration from the São Paulo School of Business at the Fundação Getúlio Vargas (EAESP-FGV). Master in Production Engineering from the Federal University of Rio de Janeiro (UFRJ). Bachelor in Economics from Fluminense Federal University (UFF). Full professor at the Federal Rural University of Rio de Janeiro (UFRRJ), working on the Graduate Program in Science, Technology, and Innovation in Agriculture and in the Graduate Program in Territorial Development and Public Policies. E-mail: cezar.eco@gmail.com, Orcid: http://orcid.org/0000-0003-2287-3948 